\title{
Effect of implanting bull calves with testosterone propionate, dihydrotestosterone propionate or oestradiol- $17 \beta$ prepubertally on the pituitary-testicular axis and on postpubertal social and sexual behaviour
}

\author{
R. W. Godfrey*, D. D. Lunstra $†$ and B. D. Schanbacher \\ US Department of Agriculture, Agricultural Research Service Reproduction Research Unit, R.L. \\ Hruska US Meat Animal Research Center, PO Box 166, Clay Center, NE 68933, USA
}

\begin{abstract}
Summary. Twelve non-implanted crossbred bull calves served as controls and 30 crossbred bull calves (10/treatment) were implanted for 82 days, beginning at 34 days of age, to determine the influence of testosterone propionate (TP), dihydrotestosterone propionate (DHTP) and oestradiol-17 $\beta$ (E2) on prepubertal and pubertal pituitarytesticular function and on postpubertal social and sexual behaviour. Compared with control bulls, concentrations of serum luteinizing hormone $(\mathrm{LH})$, follicle-stimulating hormone (FSH) and inhibin concentrations were suppressed $(P<0.01)$ in all implanted bulls. Testosterone (T) concentration increased $(P<0.001)$ in TP-implanted, but decreased $(P<0.01)$ in DHTP and E2 bulls during the implant period. LH response to gonadotrophin-releasing hormone $(\mathrm{GnRH})$ challenge during the implant period $(2 \cdot 5$ months of age) was less $(P<0.01)$ in TP, E2 and DHTP bulls than in controls. A small but significant $\mathrm{T}$ response to GnRH occurred in control bulls at 2.5 months of age. LH and T responses to GnRH challenge at 7 months of age (100 days after implant removal) was similar $(P>0.20)$ in control and implanted bulls. Steroid implants administered prepubertally had no effect $(P>0 \cdot 10)$ on postpubertal social and sexual behaviours, including number of flehmen responses, abortive mounts, services and competitive order score. Body weight did not differ $(P>0 \cdot 10)$ between treatment groups, but testis size was reduced $(P<0.01)$ during the implant period and up to 10 months of age in treated bulls compared with controls. Testes remained smaller in E2-treated bulls up to the end of the study ( 23 months of age), but daily sperm production and epididymal weight did not differ $(P>0 \cdot 10)$ between treatment groups at slaughter. Control bulls reached puberty earlier $(P<0.01 ; 270 \pm 11$ days of age $)$ than did TP (302 \pm 11 days), DHTP (309 \pm 11 days) or E2 (327 \pm 11 days) bulls. Although puberty was delayed in all implant groups, there was no difference in scrotal circumference at puberty (average $28.4 \pm 0.4 \mathrm{~cm}$ ) between treatment groups. Our findings indicate that TP, DHTP and E2 implants administered prepubertally result in acute suppression of serum $\mathrm{LH}, \mathrm{FSH}$ and inhibin during the implant period and in postimplant suppression of testis size and delayed puberty in bulls. The lack of treatment effect on behaviour suggests that steroidal programming of sexual behaviour occurs before I month of age in bulls.
\end{abstract}

Kelwords: implants; steroids; gonadotrophins; behaviour; bull

\footnotetext{
*Present address: Center for Reproduction of Endangered Wildlife, Cincinnati Zoological and Botanical Gardens, 3400 Vine Street, Cincinnati, OH 45220, USA.

$\uparrow$ Reprint requests.
} 


\section{Introduction}

Sex-specific differentiation of sexual behaviour in bovine males appears to occur primarily during prenatal development via masculinization of the brain upon exposure to steroids produced by the fetal testis in utero (Ford \& D'Occhio, 1989). However, evidence is accumulating for a number of species indicating that manifestation of postpubertal sexual behaviour is a cumulative effect influenced by several consecutive prenatal and postnatal periods of exposure to testicular steroids (Ford \& D'Occhio, 1989). Mattner et al. (1976) reported an increase in postpubertal serving activity in rams that had been implanted with exogenous testosterone (T) during early postnatal development (5-8 weeks of age). To our knowledge, studies of the effects of steroid treatments during early postnatal development on postpubertal sexual behaviour have not been attempted in intact bulls. However, Bass et al. (1977) reported that early postnatal treatment of bull calves (1-21 days of age) with daily injections of oestradiol benzoate had no subsequent effect on postpubertal bull-bull mounting activity or social aggression.

The steroidogenic capacity of bull testes is low during the first few months of postnatal life (Karg et al., 1976; Rawlings \& Cook, 1986), serum concentrations of androstenedione and individual $5 \alpha$-reduced androgens (androsterone, DHT, $5 \alpha$-androstane- $3 \alpha, 17 \beta$-diol and $5 \alpha$-androstane$3 \beta, 17 \beta$-diol) do not exceed that of serum $\mathrm{T}$ at any time from birth to 28 weeks of age (Rawlings $\&$ Cook, 1986) and serum T increases to adult concentrations by 10 months of age (Lunstra et al., 1978; Rawlings et al., 1978; Amann \& Schanbacher, 1983; Amann \& Walker, 1983; Rawlings \& Cook, 1986). Thus, administration of exogenous steroids to bulls during the first few months of life would markedly increase the amount of steroid reaching the brain and may modify subsequent sexual behaviour. Such steroidal programming of the brain for male sexual behaviour apparently occurs prepubertally in bulls, since serum $T$ concentrations in intact postpubertal bulls have no relationship to levels of libido or serving capacity (Blockey \& Galloway, 1978; Chenoweth et al., 1979; Lunstra, 1986; Price et al., 1986; Lunstra et al., 1989) and administration of T or E2 to castrated bulls restores male sexual behaviour, but mounting and serving activity are not increased above precastration levels by such treatments (Blockey \& Galloway, 1978; Sawyer \& Fulkerson, 1981; Dykeman et al., 1982). Some typically postpubertal sexual behaviour is exhibited by young bull calves (beyond 4 months of age), but appears to have little relationship to serum hormone concentrations or to reproductive performance as adults (Bass et al., 1977; Chenoweth, 1983). It has been proposed that oestrogens, via aromatization of $\mathrm{T}$ in the brain, are the central mediators of sexual responses in male ruminants (Dykeman et al., 1982; D'Occhio, 1983). However, DHT has also been shown to partially stimulate sexual behaviour in castrated bulls (Sawyer \& Fulkerson, 1981; Dykeman et al., 1982). In the present study, prepubertal bull calves were implanted with testosterone propionate (TP), DHT propionate (DHTP) or oestradiol-17 $\beta$ (E2) to evaluate the effect of these steroids on the pituitary-testicular axis during prepubertal and pubertal development and to evaluate effects on subsequent postpubertal social and sexual behaviour of these bulls.

\section{Materials and Methods}

\footnotetext{
Animals and treatments. Forty-two, spring-born, crossbred bull calves were allotted at random to four treatment groups. Groups of ten bulls were implanted with TP, DHTP, or E2, and 12 non-implanted bulls served as controls. Each hormone implant consisted of Silastic tubing $(3.35 \mathrm{~mm}$ i.d. $\times 4.65 \mathrm{~mm}$ o.d. $\times 270$ or $300 \mathrm{~mm}$ length $)$ filled with crystalline TP (300 mm; Sigma Chemical Co., St Louis, MO, USA), DHTP (300 mm; Sigma) or E2 (270 mm; Sigma) and sealed with Silastic medical adhesive (Schanbacher, 1981). Implants (one per animal) were inserted subdermally over the axillary rib region of each calf using a surgical trocar under local anaesthesia and aseptic conditions. Bulls were $34.4 \pm 0.6$ (mean \pm s.e.m.) days of age when implants were inserted. Implants remained in place for 82 days (i.e. implant period from 34 to 116 days of age).

All bull calves were reared together from 2 weeks of age, weaned at 6 months and maintained together throughout the experiment. One control bull died during the implant period, of causes unrelated to treatment.
} 
Blood sampling. On the day that the bulls were implanted ( 34 days of age) and at $\sim 14$-day intervals during the implant period, a single $25-\mathrm{ml}$ blood sample was collected via jugular venepuncture from each bull. Midway through the implant period (Day 41 of the implant period, 75 days of age), all bulls were injected (i.m.) with gonadotrophinreleasing hormone ( $\mathrm{GnRH} ; 200 \mathrm{ng} / \mathrm{kg}$ ) and blood samples $(25 \mathrm{ml})$ were collected via jugular venepuncture at $0,30,90$, 180 and $360 \mathrm{~min}$ from each bull. At 100 days after implant removal (i.e. 216 days of age, $\sim 5$ weeks after weaning), 8 calves in each treatment group were given a second GnRH challenge $(200 \mathrm{ng} / \mathrm{kg}$; i.m.). Blood samples $(25 \mathrm{ml})$ were collected via indwelling jugular catheters at 15 -min intervals for $3 \mathrm{~h}$ before and $2 \mathrm{~h}$ after $\mathrm{GnRH}$ administration and then hourly for $4 \mathrm{~h}$. This more frequent sampling was used for the second $\mathrm{GnRH}$ challenge to assess possible differences in $\mathbf{L H}$ and $\mathrm{T}$ baseline concentrations and response patterns among treatment groups and to evaluate relationships to subsequent social and sexual behaviour. All blood samples were refrigerated overnight, centrifuged at $1000 \mathrm{~g}$ for $30 \mathrm{~min}$ to yield serum and stored frozen at $-20^{\circ} \mathrm{C}$ until assayed.

Body and testicular growth. Body weight and testes measurements were recorded for each bull at (i) 34,75 and 116 days of age (i.e. Days 0,41 and 82 of the implant period); (ii) 28-day intervals from implant removal to weaning; (iii) 14-day intervals from weaning until 12 months of age; and (iv) 14, 17 and 22 months of age. Scrotal circumference and the length of each testis were measured; average testis length and paired testes volume were calculated using the formulae described by Lunstra et al. (1988).

Pubertal status was determined by electroejaculation and evaluation of semen from each bull at 14-day intervals from 7 to 12 months of age, using procedures described by Lunstra et al. (1978). A bull was considered to be pubertal when an ejaculate was first produced that contained at least $50 \times 10^{6}$ sperm cells with $\geqslant 10 \%$ progressive motility (Lunstra et al., 1978).

Evaluation of sexual behaviour. The first serving capacity tests (Test 1) were conducted when bulls were 14 months old: all bulls were subjected to a 30-min test once every 4 days during a 9-day period (i.e. 4-day intervals; Lunstra, 1980, 1986). Bulls were randomly assigned into subgroups of four or five bulls (each subgroup contained at least one bull from each of the four treatment groups) and serving capacity tests were conducted by placing each subgroup of bulls into a pen containing four restrained, oestrus-induced, ovariectomized heifers for $30 \mathrm{~min}$. Each subgroup of bulls was placed in a pen adjacent to the test pen and allowed to observe other bulls mounting and mating heifers for $30 \mathrm{~min}$ prior to being tested (Lunstra, 1980, 1986). During each serving capacity test, the number of flehmen responses, abortive mounts (i.e. mounts that did not culminate in intromission and ejaculation) and services achieved by each bull was recorded.

A second set of three serving capacity tests (Test 2 ) was conducted when bulls were $\sim 17$ months old ( 90 days after Test 1). These results were conducted in the same manner as Test 1 , except that, after the first day of testing, all bulls with $\leqslant 2$ services were placed in a paddock with 12 unrestrained, oestrus-induced heifers for 3 days to allow the bulls to gain additional experience (Boyd \& Corah, 1988; Boyd et al., 1989). Twelve additional oestrus-induced heifers were added to the paddock each day.

All bulls were subjected to a third set of serving capacity tests (Test 3 ) when bulls were $\sim 22$ months old ( 150 days after Test 2) and as described for Test 1.

Evaluation of social order. Competitive order evaluations to determine social hierarchy were conducted when bulls were 15 months old. Competitive order was determined by resource deprivation (Godfrey \& Lunstra, 1989). Bulls were randomly assigned into subgroups of four or five (each subgroup contained at least one bull from each of the four treatment groups) and feed and water were withheld overnight $(15 \mathrm{~h})$. On the following day, two subgroups of bulls were placed together in a pen wherein only one bull at a time was able to gain access to water. Competitive order in these bulls was observed for $20 \mathrm{~min}$ per pair of subgroups, and the order and frequency that each bull gained and controlled access to the water supply was recorded. Tests were conducted every other day until each subgroup of bulls had been tested against all other subgroups. Bulls remained in the same subgroup throughout the competitive order tests. Each bull was assigned a competitive order score based on the order, frequency and duration that the bull controlled access to the water during competition against all other bulls. A score of I was the most competitive and 41 was the least competitive score. Only 41 bulls were evaluated because one control bull died during the implant period.

Data at slaughter. Testes were obtained from each bull at slaughter (23 months of age). Testis weight, length and width were collected and paired testes volume was calculated (Lunstra et al., 1988). Total testicular spermatozoa was determined using the method of Schanbacher et al. (1982). A divisor of 5.32 days was used to determine total daily sperm production from total testicular spermatozoa (Amann et al., 1974).

Hormone assays. Testosterone concentrations were determined in duplicate $100 \mu$ laliquots of samples collected during the implant period and at both $\mathrm{GnRH}$ challenges by a direct radioimmunoassay (RIA; Schanbacher \& D'Occhio, 1982). Luteinizing hormone ( $\mathrm{LH}$ ) concentrations were determined in duplicate $200 \mu$ laliquots of the same samples by double-antibody RIA (Schanbacher \& Echternkamp, 1978); NIH-LH-B10 was used as the reference standard. Follicle-stimulating hormone (FSH) concentrations were determined in duplicate $100 \mu$ aliquots of samples collected during the implant period by double-antibody RIA procedure (Schanbacher, 1979); USDA-FSH-BI was used as the reference standard. Inhibin concentrations were measured in duplicate $100 \mu \mathrm{l}$ aliquots of all samples collected during the implant period by double-antibody RIA (Schanbacher, 1988); synthetic porcine inhibin $\alpha$ (amino acids 1-30) was used as both the reference standard and labelled hormone in the assay. Assay sensitivities for T, LH, FSH and inhibin were $0.1 \mathrm{ng} / \mathrm{ml}, 0.5 \mathrm{ng} / \mathrm{ml}, 30 \mathrm{ng} / \mathrm{ml}$ and $12.5 \mathrm{fmol} / \mathrm{ml}$, respectively. All assays had inter- and intra-assay coefficients of variation $<12 \%$. 
Serum concentrations of E2 and DHT were not measured, but previous experience indicated that the Silastic implants used would maintain serum oestradiol $>10 \mathrm{pg} / \mathrm{ml}$ (Schanbacher et al., 1982) and serum $\mathrm{T}$ and DHT at $26 \mathrm{ng} / \mathrm{ml}$ (B. D. Schanbacher, unpublished) in bull calves.

Statistical analysis. All data were analysed by least-squares analysis of variance techniques using the Statistical Analysis System (SAS) General Linear Models (GLM) package (SAS, 1985). Body weight, scrotal circumference and paired testes volume were analysed using a split-plot model. The whole plot consisted of treatment group, and bull within treatment group was the error term. The subplot contained time after implant and its interaction with treatment group. The one control bull that died during the implant period was eliminated from the data set. Hormone concentrations during the implant period were analysed using the same model as for body and testis size. Hormone concentrations at both $\mathrm{GnRH}$ challenges were analysed using the same model, except that 'time after GnRH' replaced 'time after implant'. For LH and $T$ in pre- and post-GnRH samples, the baseline concentration, number of peaks, number of samples included in each peak, peak amplitude and peak area $(\mathrm{ng} / \mathrm{ml} \times \mathrm{min})$ were calculated for each bull using a microcomputerized program (RIA Profile, provided by Dr W. E. Trout) that employed the algorithm described by Goodman \& Karsch (1980). Baseline concentration for each bull was calculated from the average of the lowest one-third of values obtained during each sampling period. Behavioural data from serving capacity tests were analysed by a split-plot similar to the one used for growth, with 'serving capacity test number' (Test 1,2 or 3 ) replacing 'time after implant'. For Test 1 and Test 2, only the number of behavioural events during the second and third serving capacity tests were analysed, as the bulls in each group were inexperienced during the first test. Data for social behaviour (competitive order), age at puberty and daily sperm production were analysed using treatment as the main effect in the model. Least-squares means and standard errors were generated for each hormonal, pubertal and behavioural trait. Pearson correlation coefficients were computed across all bulls and by treatment group among all factors measured. Significant differences in least-squares means were determined with Student's $t$ test (Steel \& Torrie, $1960)$ using the predicted difference (PDIFF) option of SAS GLM.

\section{Results}

Throughout the 12-week implant period, average serum $\mathrm{LH}(\mathrm{ng} / \mathrm{ml}), \mathrm{FSH}(\mathrm{ng} / \mathrm{ml})$ and inhibin (pmol/1) concentrations were reduced $(P<0.001)$ in TP $(0.9 \pm 0 \cdot 1,19 \cdot 7 \pm 1 \cdot 3$ and $96.4 \pm 2 \cdot 7)$, DHTP $(1 \cdot 0 \pm 0 \cdot 1,18 \cdot 8 \pm 1 \cdot 4$ and $108 \cdot 1 \pm 2 \cdot 7)$ and in E2 implanted calves $(1 \cdot 1 \pm 0 \cdot 1,17 \cdot 0 \pm 1 \cdot 3$ and $98.9 \pm 2 \cdot 7)$ compared with control calves $(1 \cdot 7 \pm 0 \cdot 1,48 \cdot 2 \pm 1 \cdot 3$ and $148 \cdot 2 \pm 2 \cdot 7$, respectively), particularly during the last 6 weeks of the implant period (Fig. 1). Serum T concentration, averaged throughout the implant period (Fig. 1), was highest $(P<0 \cdot 001)$ in TP calves $(3.9 \pm 0 \cdot 1)$, intermediate in control calves $(1 \cdot 0 \pm 0 \cdot 1)$, and lowest $(P<0 \cdot 001)$ in DHTP $(0 \cdot 4 \pm 0 \cdot 1)$ and E2 calves $(0 \cdot 3 \pm 0 \cdot 1 \mathrm{ng} / \mathrm{ml})$. Concentration of serum $\mathrm{T}$, averaged throughout the implant period, in TPimplanted bulls (range 2.8 to $5 \cdot 1 \mathrm{ng} / \mathrm{ml}$ ) was similar to serum levels normally present in postpubertal and adult bulls.

Baseline LH and T concentrations were lower $(P<0.05)$ in implanted bulls than in control bulls at the GnRH challenge administered at 75 days of age (Table 1). Luteinizing hormone peak amplitude $(P<0.01)$ and area $(P<0.05)$ were suppressed in all three implant groups compared to controls. Every control bull exhibited a significant $\mathrm{LH}$ and $\mathrm{T}$ response after $\mathrm{GnRH}$, but the increase in $\mathrm{T}$ was relatively small (amplitude of $0.9 \mathrm{ng} / \mathrm{ml}$ above baseline levels; $P<0.01$ ). All implanted bulls exhibited a significant and similar LH response after GnRH administration, but only $60 \%$ of the implanted bulls (18 of 30 ) exhibited a significant $\mathrm{T}$ response after $\mathrm{GnRH}$ (Table 1), and the magnitude of the T response was very small $(0.2$ to $0.6 \mathrm{ng} / \mathrm{ml})$ within those implanted bulls that did respond.

At 216 days of age (100 days after implant removal), all animals in each treatment group responded to $\mathrm{GnRH}$ with a large increase in serum $\mathrm{LH}$, and the majority of bulls $(87 \cdot 5 \%)$ exhibited a large increase in serum T (Table 1). There was no difference $(P>0 \cdot 20)$ between treatments in magnitude of $\mathrm{LH}$ and $\mathrm{T}$ responses at 30 and $90 \mathrm{~min}$, respectively (Table 1). Each of the four bulls (Table 1) that exhibited no significant $T$ increase after the GnRH challenge at 216 days of age had high endogenous levels of serum $\mathrm{T}$ at the time that $\mathrm{GnRH}$ was injected. There was no difference $(P>0 \cdot 10)$ between treatment groups in serum inhibin concentration immediately prior to GnRH $(76 \cdot 8 \pm 7 \cdot 2,72 \cdot 4 \pm 7 \cdot 2 ; 78 \cdot 4 \pm 7 \cdot 2$ and $75 \cdot 7 \pm 7 \cdot 2 \mathrm{pM}$ in control, TP, DHTP and E2 bulls, respectively). However, FSH concentration prior to GnRH was greater in E2 calves $(P<0.03$; $35.3 \pm 4.5 \mathrm{ng} / \mathrm{ml})$ than in control, TP or DHTP calves $(19.8 \pm 4.5,21.7 \pm 4.5$ and $15 \cdot 6 \pm 4 \cdot 9 \mathrm{ng} / \mathrm{ml}$, respectively). 

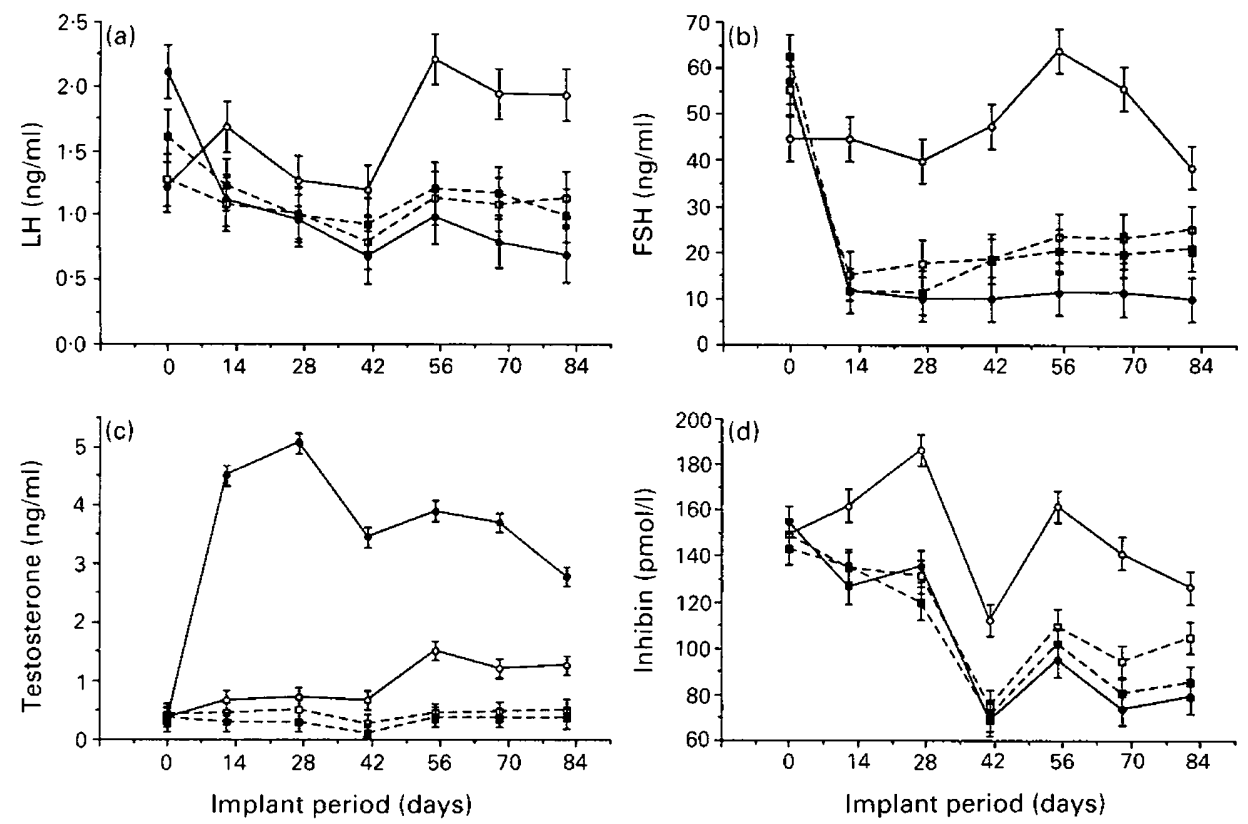

Fig. 1. Serum concentrations of (a) luteinizing hormone ( $\mathrm{LH}$ ), (b) follicle-stimulating hormone (FSH), (c) testosterone and (d) inhibin throughout the implant period (34-116 days of age) in bull calves implanted with testosterone propionate $(\bullet)$, dihydrotestosterone propionate $(\square)$ or oestradiol-17ß $(\boldsymbol{Q})$ and in control $(O)$ bull calves.

Body weight did not differ $(P>0 \cdot 10)$ between treatment groups at any time during the study (Fig. 2). However, scrotal circumference and paired testes volume were reduced $(P<0.003)$ during the implant period in all implanted bull calves (TP, DHTP and E2) compared to control bulls (Fig. 2 ), and the reduction during the implant period was of a similar magnitude for the three implant groups. Both scrotal circumference and paired testes volume remained smaller $(P<0 \cdot 05)$ from $\sim 120$ to 300 days of age in TP, DHTP and E2 calves than in control calves (Fig. 2). Bulls implanted with $\mathrm{E} 2$ had a smaller scrotal circumference $(P<0.05)$ and paired testes volume $(P<0.01)$ than did control, TP and DHTP bulls from $\sim 300$ to 360 days of age (Fig. 2), and E2 bulls had lower paired testes volume and testes weight $(P<0.05)$ than did control and TP bulls at slaughter $(23$ months of age; Table 2). However, total daily sperm production and epididymal weight did not differ $(P>0 \cdot 10)$ between treatment groups at slaughter (Table 2).

Control bulls reached puberty 32 to 57 days earlier $(P<0.05)$ than did TP, DHTP and E2 bulls (Table 3). The two implanted groups (DHTP and E2 bulls), which showed the longest delay ( 39 and 57 days, respectively) in pubertal age, reached puberty at heavier $(P<0.05)$ body weights than did controls, but there were no differences $(P>0 \cdot 20)$ between treatment groups in scrotal circumference and paired testes volume at puberty (Table 3 ).

Testis size parameters (scrotal circumference and paired testes volume) were highly correlated ( $r=0.60$ to $0.68 ; P<0.01$ ) with all characteristics of serum LH (mean, baseline, peak amplitude and area) at the first GnRH challenge (75 days of age). Testis size parameters were correlated $(r=0.32$ to $0.48 ; P<0.05$ to 0.01$)$ with T peak amplitude and area at the first GnRH challenge (75 days of age). Serum LH baseline was negatively correlated $(r=-0.47$ to $-0.42 ; P<0.01)$ with testis size parameters at the second GnRH challenge (216 days of age). Age at puberty was negatively correlated with GnRH-stimulated LH peak amplitude at 75 days of age $(r=-0.33 ; P<0.05)$ and T amplitude at 216 days of age $(r=-0.41 ; P<0.05)$. 
Table 1. Baseline, peak amplitude and peak area for serum luteinizing hormone (LH) and testosterone after gonadotrophin-releasing hormone $(\mathrm{GnRH})$ challenge $(200 \mathrm{ng} / \mathrm{kg} ; \mathrm{i} . \mathrm{m}$.) administered at 75 days of age (Day 41 of the 12-week implant period) and at 216 days of age (100 days after implant removal) in control bull calves and in bull calves that had been implanted at 34 days of age with testosterone propionate (TP), dihydrotestosterone propionate (DHTP) or oestradiol-17 $\beta$ (E2)

\begin{tabular}{|c|c|c|c|c|}
\hline & Control & TP-implanted & DHTP-implanted & E2-implanted \\
\hline \multicolumn{5}{|l|}{ GnRH challenge (75 days of age) } \\
\hline LH baseline $(\mathrm{ng} / \mathrm{ml})$ & $1 \cdot 2 \pm 0 \cdot 1^{\mathrm{b}}$ & $0 \cdot 6 \pm 0 \cdot 1^{\mathrm{d}}$ & $0.7 \pm 0 \cdot 1^{\mathrm{c} . \mathrm{d}}$ & $0 \cdot 9 \pm 0 \cdot 1^{\mathrm{c}}$ \\
\hline Bulls responding $(\%)^{\mathrm{a}}$ & $100(11 / 11)^{\mathrm{e}}$ & $100(10 / 10)^{\mathrm{C}}$ & $100(10 / 10)^{\mathrm{e}}$ & $100(10 / 10)^{e}$ \\
\hline LH peak amplitude (ng/ml) & $40 \cdot 6 \pm 4 \cdot 0^{\mathrm{b}}$ & $14 \cdot 4 \pm 4 \cdot 2^{\mathrm{c}}$ & $12 \cdot 3 \pm 4 \cdot 2^{c}$ & $19 \cdot 0+4 \cdot 2^{c}$ \\
\hline $\mathrm{LH}$ peak area $(\mathrm{ng} / \mathrm{ml} \times \mathrm{min})$ & $534 \pm 49^{\mathrm{e}}$ & $196 \pm 51^{\mathrm{f} .8}$ & $168 \pm 51^{8}$ & $318 \pm 51^{i}$ \\
\hline $\mathrm{T}$ baseline $(\mathrm{ng} / \mathrm{ml})$ & $0 \cdot 4 \pm 0 \cdot 1^{r}$ & $2 \cdot 6 \pm 0 \cdot 1^{\mathrm{c}}$ & $0 \cdot 1 \pm 0.1^{8}$ & $0.1 \pm 0.1^{g}$ \\
\hline Bulls responding $(\%)^{a}$ & $100(11 / 11)^{\mathrm{e}}$ & $20(2 / 10)^{\mathrm{g}}$ & $70(\overline{7} / 10)^{\mathrm{f}}$ & $90(9 / 10)^{\text {e.f }}$ \\
\hline T peak amplitude $(\mathrm{ng} / \mathrm{ml})$ & $1 \cdot 3 \pm 0 \cdot 3^{f}$ & $3 \cdot 0 \pm 0 \cdot 3^{\mathrm{e}}$ & $0.7 \pm 0.3^{\mathrm{f} .8}$ & $0 \cdot 3 \pm 0 \cdot 3^{8}$ \\
\hline T peak area $(\mathrm{ng} / \mathrm{ml} \times \mathrm{min})$ & $31 \cdot 9 \pm 5 \cdot 7^{\mathrm{e}}$ & $15 \cdot 2 \pm 6 \cdot 0^{f}$ & $11 \cdot 4 \pm 6 \cdot 0^{r}$ & $7 \cdot 1 \pm 6 \cdot 0^{f}$ \\
\hline \multicolumn{5}{|l|}{ GnRH challenge ( 216 days of age) } \\
\hline LH baseline $(\mathrm{ng} / \mathrm{ml})$ & $1 \cdot 0+0 \cdot 1^{\mathrm{c}}$ & $1 \cdot 1+0 \cdot 1^{\mathrm{e}}$ & $1 \cdot 0+0 \cdot 1^{\mathrm{e}}$ & $1 \cdot 2+0.1^{\mathrm{e}}$ \\
\hline Bulls responding $(\%)^{\mathrm{a}}$ & $100(\overline{8} / 8)^{\mathrm{c}}$ & $100(\overline{8} / 8)^{\mathrm{e}}$ & $100(8 / 8)^{\mathrm{c}}$ & $100(\overline{8} / 8)^{\mathrm{e}}$ \\
\hline LH peak amplitude $(\mathrm{ng} / \mathrm{ml})$ & $32 \cdot 3+3 \cdot 6^{\mathrm{c}}$ & $33 \cdot 2+3 \cdot 6^{\mathrm{c}}$ & $27 \cdot 1+3 \cdot 6^{\mathrm{c}}$ & $30 \cdot 1+3 \cdot 6^{\mathrm{c}}$ \\
\hline LH peak area $(\mathrm{ng} / \mathrm{ml} \times \min )$ & $1834 \pm 287^{\circ}$ & $2022 \pm 287^{\mathrm{c}}$ & $1647 \pm 287^{\circ}$ & $1838 \pm 287^{\circ}$ \\
\hline $\mathrm{T}$ baseline (ng/ml) & $1 \cdot 3 \pm 0.3^{\mathrm{e}}$ & $1.2 \pm 0.3^{\mathrm{e}}$ & $2 \cdot 1 \pm 0 \cdot 3^{\mathrm{e}}$ & $1.4 \pm 0 \cdot 3^{\mathrm{e}}$ \\
\hline Bulls responding $(\%)^{a}$ & $88(7 / 8)^{\mathrm{e}}$ & $88(7 / 8)^{\mathrm{e}}$ & $75(6 / 8)^{e}$ & $100(8 / 8)^{\mathrm{e}}$ \\
\hline T peak amplitude $(\mathrm{ng} / \mathrm{ml})$ & $19 \cdot 3 \pm 2 \cdot 3^{\mathrm{e}}$ & $16 \cdot 3 \pm 2 \cdot 3^{c}$ & $14 \cdot 5 \pm 2 \cdot 3^{c}$ & $14 \cdot 9 \pm 2 \cdot 3^{e}$ \\
\hline $\mathrm{T}$ peak area $(\mathrm{ng} / \mathrm{ml} \times \mathrm{min})$ & $778 \pm 178^{\circ}$ & $754 \pm 178^{\mathrm{e}}$ & $608 \pm 178^{\mathrm{e}}$ & $742 \pm 178^{\circ}$ \\
\hline
\end{tabular}

${ }^{\text {a }}$ Proportion of bulls exhibiting a significant hormone peak $(P<0.05$ response) within $30 \mathrm{~min}$ (LH) or $90 \mathrm{~min}$ (testosterone) after GnRH injection.

b.c,dValues (mean \pm s.e.m.) with different superscripts within a row $\operatorname{differ}(P<0.01)$.

e.f.g Values (mean \pm s.e.m.) with different superscripts within a row differ $(P<0 \cdot 05)$.

Social order (mean \pm s.e.m. competitive order score) at 15 months of age did not differ $(P>0.10)$ between control, TP, DHTP and E2 treatment groups $(22.4 \pm 3.6,24.0 \pm 3.8$, $16.0 \pm 3.8$ and $21.5 \pm 3.8$; respectively). Treatment groups did not differ $(P>0.10)$ in number of flehmen responses, abortive mounts and services achieved during serving capacity tests at 14, 17 and 22 months of age (Test 1, Test 2 and Test 3, respectively; Fig. 3). The number of services increased $(P<0.01)$ and number of abortive mounts decreased $(P<0.01)$ between 14 and 17 months of age (Test 1 and Test 2; Fig. 3), regardless of treatment, but both events appeared to stabilize $(P>0 \cdot 20)$ during the last two sets of serving capacity tests (Test 2 and Test 3$)$. There was a non-significant trend (Fig. 3) for TP-implanted bulls to have a higher number of services $(P=0 \cdot 12)$ and abortive mounts $(P=0 \cdot 10)$ than did other bulls at 14 months of age (Test 1$)$. When the number of services and abortive mounts achieved per bull (total mounts) were added together within each serving capacity test, TP-implanted bulls had a higher number of total mounts at 14 months of age (Test 1) than did the control $(P=0.01)$, DHTP $(P=0.03)$ or E2 bulls $(P=0.01)$, but total mounts did not differ significantly between treatment groups beyond 14 months of age. Postpubertal social (competitive order score) and sexual behaviour (number of flehmen responses, abortive mounts and services) were not correlated significantly with body weight, testis size, serum LH and T concentrations or GnRH-stimulated LH and T peak parameters at either age tested (75 days and 216 days of age).

\section{Discussion}

Mattner et al. (1976) were able to increase postpubertal serving activity of rams by administering exogenous $\mathrm{T}$ during weeks 5 to 8 after birth. In an attempt to influence the postpubertal sexual 

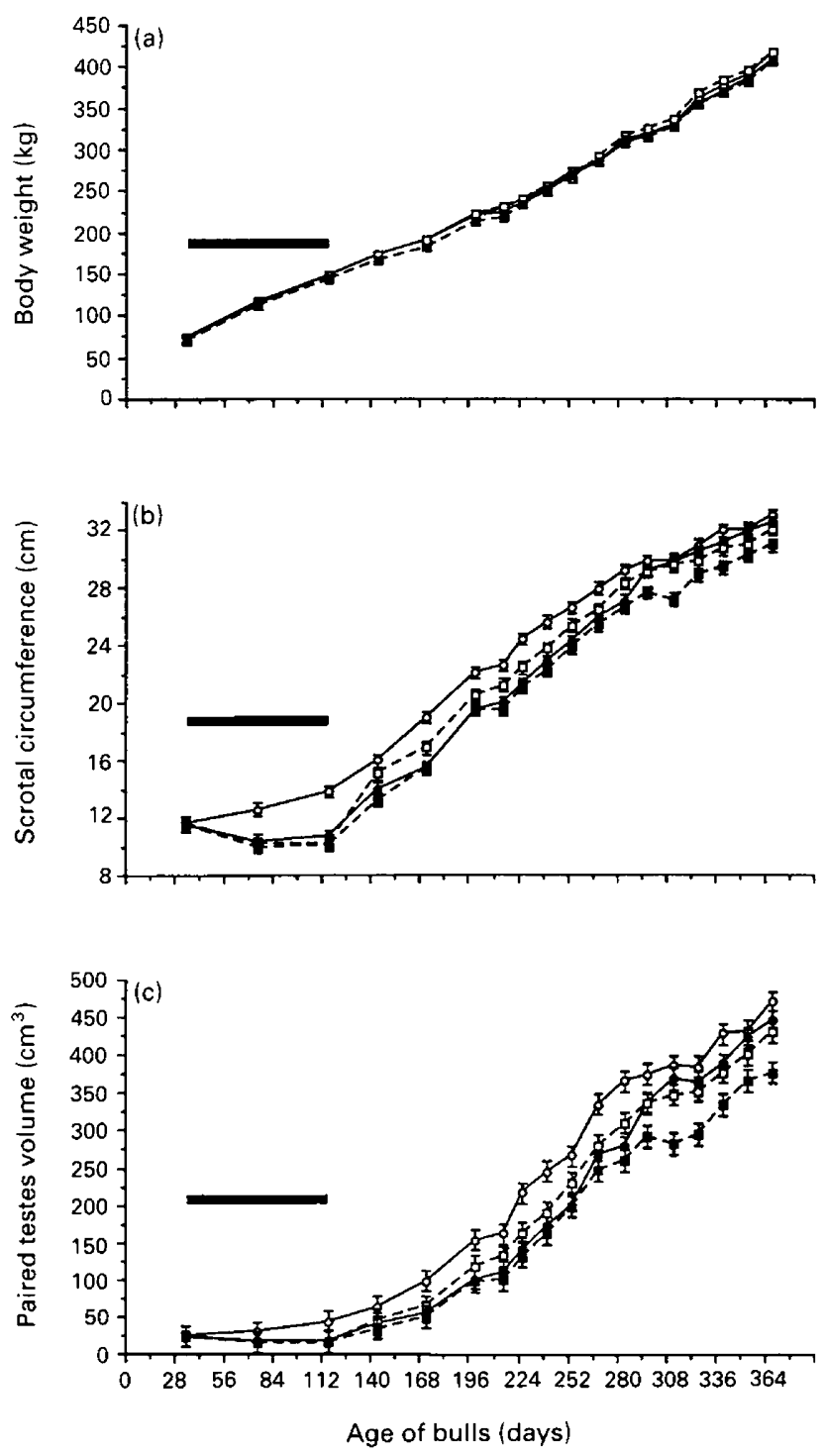

Fig. 2. Mean (a) body weight, (b) scrotal circumference and (c) paired testes volume from 34 to 365 days of age in bull calves implanted from 34 to 116 days of age with testosterone propionate $(\odot)$, dihydrotestosterone propionate $(\square)$ or oestradiol-17 $\beta(\square)$ and in control $(\bigcirc)$ bull calves. The bar indicates the duration of the implant period.

behaviour of bulls, our study increased serum levels of T, DHT and E2 in young bull calves during a physiological age similar to that when exogenous $T$ is effective in rams (Mattner et al., 1976). However, implants of T, DHT or E2 administered from 5 to 17 weeks (34 to 116 days) of age in bulls did not cause changes in postpubertal sexual behaviour, and it appears that steroid programming of sexual behaviour occurs prior to 34 days of age in the bovine male, and may occur before birth (Bass et al., 1977; Ford \& D’Occhio, 1989). Mattner et al. (1976) were unable to increase ram serving activity when $T$ implants were administered at 2 to 5 weeks or 8 to 11 weeks of age, indicating that the postnatal window when exogenous $T$ can influence sexual behaviour in rams is very narrow. It is possible that implants of exogenous steroids administered to bulls before 5 weeks 
Table 2. Mean ( \pm s.e.m.) paired epididymides weight, testes volume, testes weight and total daily sperm production at slaughter (23 months of age) in control bulls and in bulls that had been implanted from 34 to 116 days of age with testosterone propionate (TP), dihydrotestosterone propionate (DHTP) or oestradiol-17ß (E2)

\begin{tabular}{lcccc}
\hline Group & $\begin{array}{c}\text { Paired } \\
\text { epididymides } \\
\text { weight }(\mathrm{g})\end{array}$ & $\begin{array}{c}\text { Paired } \\
\text { testes weight } \\
(\mathrm{g})\end{array}$ & $\begin{array}{c}\text { Paired } \\
\text { testes volume } \\
\left(\mathrm{cm}^{3}\right)\end{array}$ & $\begin{array}{c}\text { Daily sperm } \\
\text { production } \\
\left(\times 10^{-9}\right)\end{array}$ \\
\hline Control & $64 \cdot 5 \pm 4 \cdot 5^{\mathrm{a}}$ & $688 \pm 38^{\mathrm{a}}$ & $663 \pm 36^{\mathrm{a}}$ & $6 \cdot 9 \pm 0 \cdot 6^{\mathrm{a}}$ \\
TP & $64 \cdot 0 \pm 5 \cdot 0^{\mathrm{a}}$ & $723 \pm 42^{\mathrm{a}}$ & $674 \pm 40^{\mathrm{a}}$ & $6 \cdot 9 \pm 0 \cdot 6^{\mathrm{a}}$ \\
DHTP & $61 \cdot 4 \pm 4 \cdot 7^{\mathrm{a}}$ & $670 \pm 40^{\mathrm{a} \cdot \mathrm{b}}$ & $643 \pm 38^{\mathrm{a}, \mathrm{b}}$ & $6 \cdot 5 \pm 0 \cdot 6^{\mathrm{a}}$ \\
E2 & $52 \cdot 9 \pm 4 \cdot 7^{\mathrm{a}}$ & $586 \pm 40^{\mathrm{b}}$ & $557 \pm 38^{\mathrm{b}}$ & $5.9 \pm 0 \cdot 6^{\mathrm{a}}$ \\
\hline
\end{tabular}

${ }^{a, b}$ Means with different superscripts within a column differ $(P<0.05)$.

Table 3. Mean ( \pm s.e.m.) pubertal age, body weight, scrotal circumference and paired testicular volume at puberty in control bulls and in bulls which had been implanted from 34 to 116 days of age with testosterone propionate (TP), dihydrotestosterone propionate

(DHTP) or oestradiol-17 $\beta$ (E2)

\begin{tabular}{lccccc}
\hline Group & $\begin{array}{c}\text { No. of } \\
\text { bulls }\end{array}$ & $\begin{array}{c}\text { Pubertal age* } \\
(\text { days })\end{array}$ & $\begin{array}{c}\text { Body weight } \\
(\mathrm{kg})\end{array}$ & $\begin{array}{c}\text { Scrotal } \\
\text { circumference } \\
(\mathrm{cm})\end{array}$ & $\begin{array}{c}\text { Paired } \\
\text { testicular volume } \\
\left(\mathrm{cm}^{3}\right)\end{array}$ \\
\hline Control & 11 & $270 \pm 10^{\mathrm{a}}$ & $287 \pm 17^{\mathrm{a}}$ & $28 \cdot 0 \pm 0 \cdot 9^{\mathrm{a}}$ & $317 \pm 27^{\mathrm{a}}$ \\
TP & 10 & $302 \pm 11^{\mathrm{b}}$ & $326 \pm 18^{\mathrm{a} b \mathrm{~b}}$ & $28 \cdot 1 \pm 0 \cdot 9^{\mathrm{a}}$ & $300 \pm 28^{\mathrm{a}}$ \\
DHTP & 10 & $309 \pm 11^{\mathrm{b}, \mathrm{c}}$ & $341 \pm 18^{\mathrm{b}}$ & $29 \cdot 3 \pm 0 \cdot 9^{\mathrm{a}}$ & $344 \pm 28^{\mathrm{a}}$ \\
E2 & 10 & $327 \pm 11^{\mathrm{c}}$ & $346 \pm 18^{\mathrm{b}}$ & $28 \cdot 4 \pm 0 \cdot 9^{\mathrm{a}}$ & $307 \pm 28^{\mathrm{a}}$ \\
\hline
\end{tabular}

a.b.c Means with different superscripts within a column differ $(P<0.05)$.

*Puberty was defined as the age when a bull first produced an ejaculate containing at least $50 \times 10^{6}$ sperm cells with $\geqslant 10 \%$ progressive motility.

or after 17 weeks of age may influence postpubertal sexual behaviour in the bovine male, but these possibilities await further study.

A tendency for bulls, which had been implanted with TP, to exhibit a higher number of services, abortive mounts and total mounts than did control bulls occurred only at 14 months of age. Mattner et al. (1976) tested the serving activity of treated rams only at one age postpubertally, and the permanency of the implant effect on ram sexual behaviour remains to be confirmed. With rams, Mattner et al. (1976) found significant differences in serving activity using 16 to 23 animals per treatment group. Among bulls in our study the variation in sexual behaviour was large within treatment group, and more than 10 bulls per treatment group may be necessary to detect subtle changes in mounting or serving activity induced by steroid implants. Lunstra $(1980,1986)$ reported that bulls become more efficient in mating activity as they gain experience, and our results support that finding, since number of services increased and abortive mounts decreased as bulls increased in age.

Implants of T, DHT or E2 administered prepubertally from 5 to 17 weeks (34 to 116 days) of age in bulls did not result in changes in postpubertal social dominance, based on competitive order score of bulls at 15 months of age. In the present study, competitive order was defined "in terms of the demonstration of priority of access" (Syme, 1974), using water as the reward. However, competitive order is not well established in young bulls, and competitive order rankings change as bulls mature (Godfrey \& Lunstra, 1989). It is also possible that the establishment of dominance relationships was slowed in the present study by rearing the bulls as one group from birth through to the 

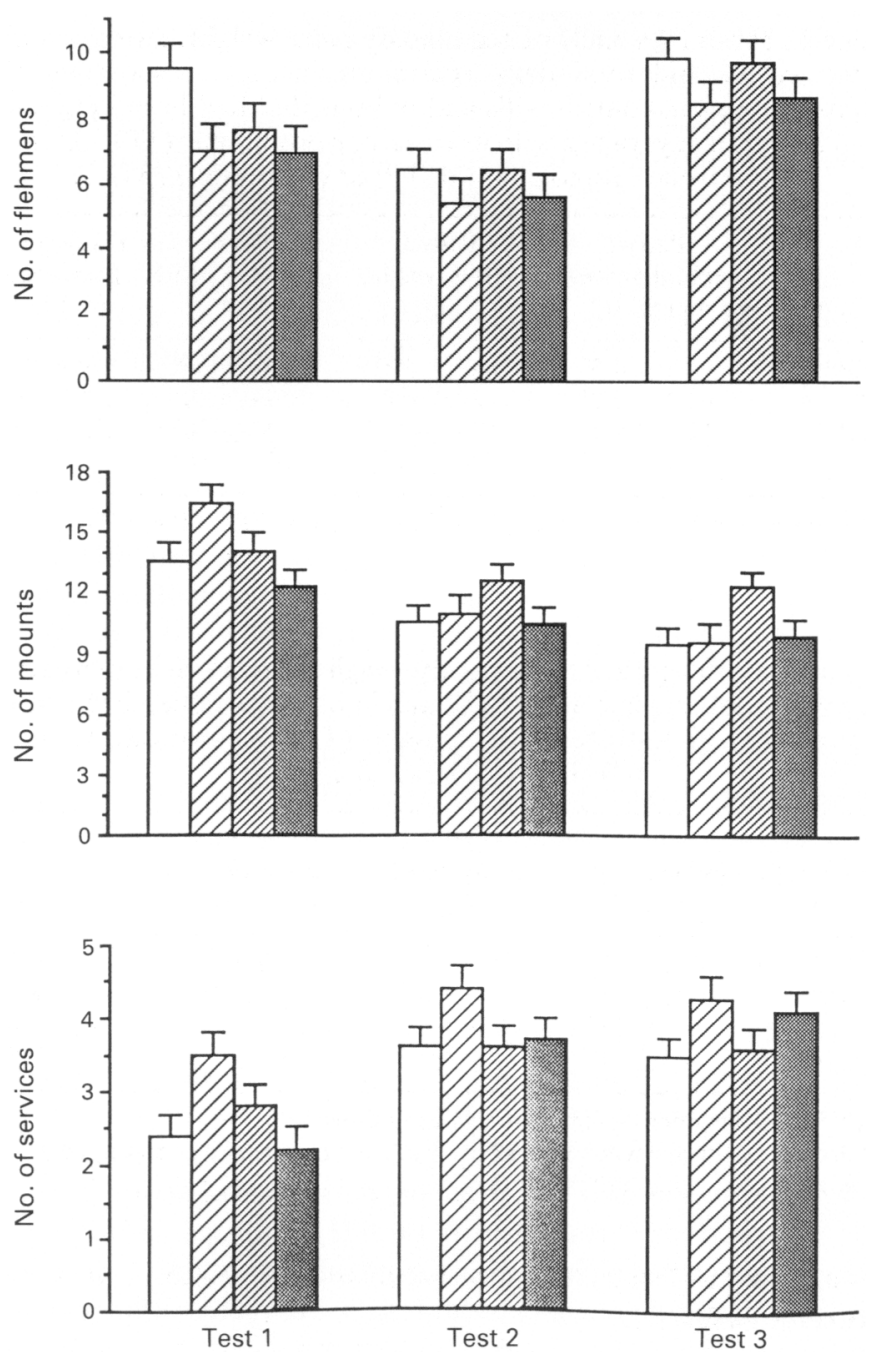

Fig. 3. Mean ( \pm s.e.m.) number of (a) flehmen responses, (b) abortive mounts and (c) services achieved during tests of sexual behaviour at 14, 17 and 22 months of age (Test 1, Test 2 and Test 3, respectively) by control bulls $(\square)$ and by bulls that had been implanted from 34 to 116 days of age with testosterone propionate $(\mathbb{Z})$, dihydrotestosterone propionate $(\mathbb{Z})$ or

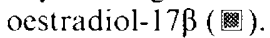

end of the experiment (Craig, 1986). Our results agree with those of Bass et al. (1977), who reported that oestradiol administered daily for 3 weeks after birth had no influence on the postpubertal social and aggressive behaviour of young bulls evaluated from 4 to 16 months of age. Our finding that no significant relationship existed between competitive order score (15 months of age) and serum concentrations of LH and T (7 months of age) agrees with Price et al. (1986), who reported that endogenous $\mathrm{LH}$ and $\mathrm{T}$ concentrations had no relationship with aggressive behaviour in 18 and 24-month-old bulls.

There has been very little success in correlating serum levels of gonadotrophins or androgens and oestrogens with sexual behaviour in bulls (Blockey \& Galloway, 1978; Lunstra et al., 1978; Chenoweth et al., 1979; Lunstra, 1986; Price et al., 1986; Lunstra et al., 1989). Intensive blood sampling has demonstrated that endogenous LH and T concentrations have no relationship with sexual behaviour in yearling (Lunstra, 1986; Lunstra et al., 1989) or 18- and 24-month-old beef 
bulls (Price et al., 1986). Thus, the lack of significant correlations between LH and T hormonal parameters at 7 months of age and postpubertal sexual behaviour in our study was not surprising.

In our study, steroid implants (TP, DHTP and E2) administered prepubertally appeared to influence both pituitary and testicular function. All three steroid implants caused suppression of LH and FSH during the implant period in prepubertal bulls, which agrees with previous reports on the negative feedback effect of T (Katongole et al., 1971; Mongkonpunya et al., 1975; Karg et al., 1976; Schanbacher \& Echternkamp, 1978; Schams et al., 1978), E2 (Schanbacher, 1981, 1984; Gettys et al., 1984) and DHT (Gettys et al., 1984; Kennedy et al., 1985) on serum LH concentrations in bulls. Kennedy et al. (1985) reported that FSH concentration can be suppressed by DHT. Karg et al. (1976) reported that increased FSH concentration was correlated with increasing $T$ concentration in the serum of bulls during prepubertal development.

All three steroids had a negative feedback effect on pituitary gonadotrophin release during the implant period which could not be overcome completely by a single dose of exogenous GnRH. Schanbacher (1984) reported that the inhibitory effects of E2 on testicular and pituitary function can be overcome only if GnRH is chronically administered in a pulsatile manner. A small but significant $\mathrm{T}$ response was elicited in all control bulls by $\mathrm{GnRH}$ at 2.5 months of age, in contrast with Mongkonpunya et al. (1975) who reported that bull testes will not respond to GnRH with an increase in $T$ prior to 6 months of age. The present study indicates that bull testes can respond to gonadotrophins before 6 months of age, although the response is very limited.

Recently, it has been shown that serum inhibin and FSH concentrations are inversely related (Schanbacher, 1988). In our study, serum levels of inhibin, FSH and LH were suppressed in steroid-implanted calves, and this indicates that there may be direct inhibitory effects of exogenous TP, DHTP and E2 on testicular inhibin production and on pituitary gonadotrophin secretion. Risbridger et al. (1989) have shown that rat Leydig cells produce immuno- and bioactive inhibin in vitro. It may be possible that bovine Leydig cells also produce inhibin, and there may have been a direct negative effect of the exogenous steroids on inhibin secretion by the testes in the present study. However, it has been reported that, in rats, Leydig cell secretions affect inhibin production by Sertoli cells (Drummond et al., 1989), and it is possible that the inhibitory effects of the implants on Leydig cell function indirectly inhibited inhibin production by Sertoli cells. In support of this concept, the suppressed biweekly concentrations of serum T in DHTP and E2 bulls $(P<0.001)$ and the suppressed $\mathrm{T}$ response to GnRH challenge in TP, DHTP and E2 bulls $(P<0.05)$ during the implant period reflect a direct inhibitory effect of exogenous steroids on Leydig cell steroidogenic capability, which could then indirectly influence inhibin secretion by Sertoli cells.

Prolonged suppression of testis size in TP-, DHTP- and E2-implanted bulls continued to 10 months of age, and puberty (spermatogenic activity) was delayed in all implanted bulls, indicating that both testis growth and testis function were impaired by these exogenous steroids for at least 6 months after implant removal. Other studies have reported that steroid implants cause a shorter period of suppressed testicular development. Schanbacher (1981) showed that implanting bulls with E2 caused a suppression of testicular growth but compensation occurred rapidly upon removal of the implant. Echternkamp \& Lunstra (1984) demonstrated that progesterone implants in prepubertal rams suppressed serum gonadotrophins, testicular size, tubule development and spermatogenesis, but that accelerated testicular development occurred after implant removal. However, our results agree with those of Godfrey et al. (1989), who reported that zeranol, an anabolic agent, causes a prolonged delay of testis growth and spermatogenesis in bulls implanted before 150 days of age. Similar serum LH, T and inhibin concentrations and responses to GnRH existed between all bull groups while implanted bulls still exhibited suppressed testis development at 7 months of age (100 days after implant removal). These data indicate that recovery of testicular endocrine function and interrelationships with gonadotrophin secretion occurred rapidly after removal of steroid implants, but testicular development recovered more slowly. E2 bulls continued to exhibit suppressed testis size to 23 months of age, although there was no difference in daily sperm 
production at slaughter. Apparently, compensatory growth was not able to overcome the setback imposed by the implants in the E2 calves, while the DHTP and TP calves achieved testes size similar to that of control bulls beyond 10 months of age. The mechanisms involved in this prolonged suppression of testicular development require further study.

Although puberty was delayed in all three implanted bull groups and significant differences in pubertal age existed between implant groups, there were no differences between treatment groups in scrotal circumference at puberty (average $28.4 \pm 0.4 \mathrm{~cm}$ ). These results agree well with our previous finding (Lunstra et al., 1978) that bulls achieve puberty when scrotal circumference reaches $28 \mathrm{~cm}$, regardless of large differences in breed, calendar age and body weight. It is interesting to note that bulls that reached puberty earliest also exhibited greater GnRH-stimulated LH and T responses during prepubertal GnRH challenges. However, the correlations between pubertal age and prepubertal GnRH-stimulated hormonal responses $(r=-0.41$ to -0.30$)$ were much lower than correlations between pubertal age and measurements of scrotal circumference between 7 and 13 months of age $(r=-0.85$ to -0.67$)$. Thus, measurement of neopubertal scrotal circumference remains as the most accurate method for predicting actual pubertal age in beef bulls (Lunstra et al., 1978).

In summary, the present study demonstrated that TP, DHTP and E2 implants during prepubertal development suppressed endogenous LH, FSH and T, and suppressed GnRH-induced secretion of $\mathrm{LH}$ and $\mathrm{T}$ in bulls at 2.5 months of age. Testicular growth and testicular production of $\mathrm{T}$ and inhibin were also suppressed by these steroids during the implant period. After implant removal, testicular endocrine function recovered rapidly but testis size and spermatogenic function recovered more slowly, and puberty was delayed in all implanted bulls. E2 implants caused a more prolonged delay of testis development and puberty than did TP and DHTP implants. Steroid implants administered prepubertally ( 1 to 4 months of age) had no effect on postpubertal social and sexual behaviour of the bulls, indicating that steroid programming of sexual behaviour probably occurs prior to 34 days of age in bulls. If a sensitive postnatal period for steroidal programming of sexual or social behaviour exists in bulls, studies to assess the influence of exposure to exogenous steroids during the first month of postnatal life in bulls are needed.

The authors would like to thank A. Kruger, G. McMillan and T. Garvin for assistance in data collection and hormone assays, D. Griess and V. Stidham for manuscript preparation, the NIDDK and USDA for LH and FSH reference preparations. Dr W. E. Trout provided a microcomputerized program (RIA Profile), based on the Goodman and Karsch algorithm, which was used for analysis of hormone profiles.

\section{References}

Amann, R.P. \& Schanbacher, B.D. (1983) Physiology of male reproduction. J. Anim. Sci. 57 (Suppl. 2), 380403 .

Amann, R.P. \& Walker, O.A. (1983) Changes in the pituitary-gonadal axis associated with puberty in Holstein bulls. J. Anim. Sci. 57, 433-442.

Amann, R.P., Kavanaugh, J.F., Griel, L.C., Jr \& Voglmayr, J.K. (1974) Sperm production of Holstein bulls determined from testicular spermatid reserves after cannulation of rete testis or vas deferens, and by daily ejaculation. J. Dairy Sci. 57, 93-99.

Bass, J.J., Peterson, A.J., Payne, E. \& Jarnet, M.P. (1977) The effect of neonatal estrogen treatment on plasma hormone levels and behaviour in pre- and post-pubertal bulls. Theriogenology 8, 59-71.

Blockey, M.A. deB. \& Galloway, D.B. (1978) Hormonal control of serving capacity in bulls. Theriogenology 9 , 143-151.
Boyd, G.W. \& Corah, L.R. (1988) Effect of sire and sexual experience on serving capacity of yearling beef bulls. Theriogenology 29, 779-790.

Boyd, G.W., Lunstra, D.D. \& Corah, L.R. (1989) Serving capacity of crossbred yearling beef bulls: I. Single-sire mating behavior and fertility during average and heavy mating loads at pasture. J. Anim. Sci. 67, $60-71$.

Chenoweth, P.J. (1983) Sexual behavior of the bull: A review. J. Dairy Sci. 66, 173-179.

Chenoweth, P.J., Brinks, J.S. \& Nett, T.M. (1979) Comparison of three methods of assessing sex-drive in yearling beef bulls and relationships with testosterone and LH levels. Theriogenology 12, 223233.

Craig, J.V. (1986) Measuring social behavior: social dominance. J. Anim. Sci. 62, 1 120-1129.

D'Occhio, M.J. (1983) Role of gonadal steroids in the mating behaviour of the ram Ovis aries $L$. Downloaded from Bioscientifica.com at 04/26/2023 10:10:37AM via free access 
Ph.D. Thesis, University of Adelaide, Adelaide, Australia.

Drummond, A.E., Risbridger, G.P. \& DeKretser, D.M. (1989) The involvement of Leydig cells in the regulation of inhibin secretion by the testis. Endocrinology 125, $510-515$.

Dykeman, D.A., Katz, L.S. \& Foote, R.H. (1982) Behavioral characteristics of beef steers administered estradiol, testosterone and dihydrotestosterone. $J$. Anim. Sci. 55, 1303-1309.

Echternkamp, S.E. \& Lunstra, D.D. (1984) Relationship between LH and testicular development in progesterone-implanted prepubertal ram lambs. J. Anim. Sci. 59, $441-453$.

Ford, J.J. \& D'Occhio, M.J. (1989) Differentiation of sexual behavior in cattle, sheep and swine. J. Anim. Sci. 67, 1816-1823.

Gettys, T.W., D'Occhio, M.J., Henricks, D.M. \& Schanbacher, B.D. (1984) Suppression of LH secretion by oestradiol, dihydrotestosterone and trenbolone acetate in the acutely castrated bull. $J$. Endocr. 100, 107-112.

Godfrey, R.W. \& Lunstra, D.D. (1989) Influence of single or multiple sires and serving capacity on mating behavior of beef bulls. J. Anim. Sci. 67, 2897-2903.

Godfrey, R.W., Randel, R.D. \& Rouquette, F.M., Jr (1989) Effect of zeranol on sexual development of crossbred bulls. J. Anim. Sci. 67, 1751-1756.

Goodman, R.L. \& Karsch, F.J. (1980) Pulsatile secretion of luteinizing hormone: differential suppression by ovarian steroids. Endocrinology 107, 1286-1290.

Karg, H., Gimenez, T., Martl, M., Hoffmann, B., Schallenberger, E. \& Schams, D. (1976) Testosterone, luteinizing hormone ( $\mathrm{LH})$ and follicle stimulating hormone (FSH) in peripheral plasma of bulls: levels from birth through puberty and short term variation. Zbl. Vet. Med. A. 23, 793-803.

Katongole, C.B., Naftolin, F. \& Short, R.V. (1971) Relationship between blood levels of luteinizing hormone and testosterone in bulls, and the effects of sexual stimulation. J. Endocr. 50, 457-466.

Kennedy, R.I., Rawlings, N.C. \& Cook, S.J. (1985) Effects of dihydrotestosterone and $5 \alpha$-androstane$3 \alpha, 17 \beta$-diol on serum concentrations of $\mathrm{LH}$ and FSH in the prepubertal bull. Can. J. Anim. Sci. 65, 95-99.

Lunstra, D.D. (1980) Evaluation of libido in beef bulls. Proc. Ann. Mig Soc. Theriogenology, pp. 169-179.

Lunstra, D.D. (1986) Libido and serving capacity of beef bulls. Proc. Beef Improvement Federation Ann. Mtg, pp. 20-36.

Lunstra, D.D., Ford, J.J. \& Echternkamp, S.E. (1978) Puberty in beef bulls: hormone concentrations, growth, testicular development, sperm production and sexual aggressiveness in bulls of different breeds. J. Anim. Sci. 46, 1054-1062.

Lunstra, D.D., Gregory, K.E. \& Cundiff, L.V. (1988) Heritability estimates and adjustment factors for the effects of bull age and age of dam on yearling testicular size in breeds of bulls. Theriogenology 30, 127-136.

Lunstra, D.D., Boyd, G.W. \& Corah, L.R. (1989) Effects of natural mating stimuli on serum luteinizing hormone (LH), testosterone (T) and estradiol-17 $\beta$
(E2) in yearling beef bulls. J. Anim. Sci. 67, 3277-3288.

Mattner, P.E., George, J.M. \& Braden, A.W.H. (1976) Testosterone treatment of ram lambs: Effect on adult libido. Theriogenology 6, 613 (abstr).

Mongkonpunya, K., Hafs, H.D., Convey, E.M., Tucker, H.A. \& Oxender, W.D. (1975) Serum luteinizing hormone, testosterone and androstenedione in pubertal and prepubertal bulls after gonadotropin releasing hormone. J. Anim. Sci. 40, 682-686.

Price, E.O., Katz, L.S., Moberg, G.P. \& Wallach, S.J.R. (1986) Inability to predict sexual and aggressive behaviors by plasma concentrations of testosterone and luteinizing hormone in Hereford bulls. J. Anim. Sci. 62, 613-617.

Rawlings, N.C. \& Cook, S.J. (1986) Plasma concentrations of testosterone, androstenedione, dihydrotestosterone, $5 \alpha$-androstane- $3 \alpha, 17 \beta$-diol, $5 \alpha$ androstane-3 $\beta, 17 \beta$-diol and androsterone in bull calves: response to hCG. Can. J. Anim. Sci. 66, 975-982.

Rawlings, N.C., Fletcher, P.W., Henricks, D.M. \& Hill, J.R. (1978) Plasma luteinizing hormone (LH) and testosterone levels during sexual maturation in beef bull calves. Biol. Reprod. 19, 1108-1112.

Risbridger, G.P., Clements, J., Robertson, D.M., Drummond, A.E., Muir, J., Burger, H.G. \& DeKretser, D.M. (1989) Immuno- and bioactive inhibin and inhibin $\alpha$-subunit expression in rat Leydig cell cultures. Mol. Cell. Endocr. 66, 119-122.

SAS (1985) User's Guide. Statistical Analysis System Institute, Inc. Cary, NC, USA.

Sawyer, G.J. \& Fulkerson, W.J. (1981) The effectiveness of steers and heifers treated with oestrogen or testosterone to detect oestrus in cattle. Anim. Reprod. Sci. $3,259-269$.

Schams, D., Gombe, S., Schallenberger, E., Reinhardt, V. \& Claus, R. (1978) Relationships between short-term variations of $\mathrm{LH}, \mathrm{FSH}$, prolactin and testosterone in peripheral plasma of prepubertal bulls. J. Reprod. Fert. 54, 145-148.

Schanbacher, B.D. (1979) Testosterone secretion in cryptorchid and intact bulls injected with gonadotropin-releasing hormone and luteinizing hormone. Endocrinology 104, 360-364.

Schanbacher, B.D. (1981) Importance of the episodic nature of luteinizing hormone secretion for normal development of the bovine testis during puberty: interference with oestradiol-17 $\beta$. J. Endocr. 88, 393-400.

Schanbacher, B.D. (1984) Pituitary-testicular responses of estradiol-17 $\beta$-implanted bull calves to continuous versus pulsatile infusion of luteinizing hormone releasing hormone. J. Anim. Sci. 58, 943-948.

Schanbacher, B.D. (1988) Radioimmunoassay of inhibin: Serum responses to unilateral and bilateral orchidectomy. Endocrinology 123, 2323-2330.

Schanbacher, B.D. \& D'Occhio, M.J. (1982) Validation of a direct radioimmunoassay for testosterone in unextracted serum from five species: application to study of the hypothalamic-pituitary-gonadal axis in males. J. Androl. 3, 45-5I

Schanbacher, B.D. \& Echternkamp, S.E. (1978) Testicular steroid secretion in response to $\mathrm{GnRH}$-mediated Downloaded from Bioscientifica.com at 04/26/2023 10:10:37AM 
LH and FSH release in bulls. J. Anim. Sci. 47, Steel, R.G.D. \& Torrie, J.H. (1960) Principles and Pro$514-520$.

Schanbacher, B.D., D'Occhio, M.J. \& Kinder, J.E. (1982)

Initiation of spermatogenesis and testicular growth in oestradiol-17ß-implanted bull calves with pulsatile infusion of luteinizing hormone releasing hormone. J. Endocr. 93, 183-192. cedures of Statistics. McGraw-Hill Book Co., New York.

Syme, G. (1974) Competitive orders as measures of social dominance. Anim. Behav. 22, 931-940.

Received 31 August 1990 